\title{
Preparation and Characterization of Films Based on Disintegrated Bacterial Cellulose and Montmorillonite
}

\author{
Agata Sommer ${ }^{1} \cdot$ Hanna Staroszczyk ${ }^{1}\left[0\right.$ - Izabela Sinkiewicz ${ }^{1} \cdot$ Piotr Bruździak $^{2}$
}

Accepted: 9 November 2020 / Published online: 23 November 2020

(c) The Author(s) 2020

\begin{abstract}
The food packaging materials from natural polymers including polysaccharides offer an ecologically important alternative to commonly used synthetic, non-biodegradable counterparts. The purpose of this work was to modify of bacterial cellulose (BC) leading to the improvement of its functional properties in terms of use as a food packaging material. Effects of disintegration of $\mathrm{BC}$ and addition of montmorillonite (MMT) on its water barrier, mechanical and thermal properties were investigated. Disintegration of BC increased its water vapour permeability (WVP) and thermal stability, but decreased its tensile strength $(\sigma)$. These changes were closely related to the rearrangement of hydrogen-bond network in the BC structure, resulting in a partial conversion from the $\mathrm{I}_{\alpha}$ to $\mathrm{I}_{\beta}$ allomorph. The addition of $2 \%$ of MMT did not affect WVP and $\sigma$ of the disintegrated BC (bBC), while the plasticization of the modified bBC generally decreased WVP, and did not increase $\sigma$. The improvement in water barrier properties of $\mathrm{bBC}$ modified by adding $2 \%$ of MMT in the presence of glycerol was caused by the formation of hydrogen bonds between the components of the composite. The results presented show the potential usefulness of BC modified by disintegration and adding $2 \%$ of MMT and 10-15\% of glycerol as a food packaging material.
\end{abstract}

Keywords Bacterial cellulose $\cdot$ Structure $\cdot$ Water barrier properties $\cdot$ Tensile strength $\cdot$ Thermal stability

\section{Introduction}

Biodegradable materials with good water barrier and mechanical properties are gaining increasing interest in the field of food packaging, including disposable packaging. Unlike synthetic materials, the use of polysaccharide-based materials provides an environmentally friendly technological solution, reducing thus the dependence on fossil resources and reducing the carbon footprint of the products [1].

Materials based on bacterial cellulose (BC) have attracted great attention due to their high purity of cellulose content, refined nanofibrous network and very low cost. BC has better properties than plant cellulose, including higher tensile strength and high fiber content. In order to develop

Hanna Staroszczyk

hanna.staroszczyk@pg.edu.pl

1 Department of Food Chemistry, Technology and Biotechnology, Gdansk University of Technology, Gabriela Narutowicza 11/12, 80-233 Gdansk, Poland

2 Department of Physical Chemistry, Gdansk University of Technology, G. Narutowicza 11/12, 80-233 Gdansk, Poland highly functional materials, various attempts have been made to produce $\mathrm{BC}$ composites, both the in situ (during $\mathrm{BC}$ synthesis) and ex situ (after BC synthesis) technique [2]. Some authors have disintegrated the previously dried $\mathrm{BC}$ membranes and mixed them with other fibrous materials [3-5] to obtain a very strong material with mechanical properties rivaling those of synthetic polymers. Other authors have incorporated polymers or solid particles in the structure of BC membrane, such as silica particles, metallic oxides, carbonates and clay materials [1,2]. Among the latter, montmorillonite (MMT) has gained attention because of the enhanced physical and mechanical properties of the final products [6-9]. Also, the water barrier properties of polymeric materials can be significantly enhanced by the addition of MMT [10]. According to Ul Islam et al. [7, 8] $\mathrm{BC}$-montmorillonite (BC/MMT) composites prepared by impregnation of $\mathrm{BC}$ membranes with MMT suspension show much better mechanical and thermal properties than native $\mathrm{BC}$; however, they have high water holding capacity and the potential to retain water for a long time. This is extremely important for wound healing purposes, but is not advisable for food packaging. 
The $\mathrm{BC}$, an unbranched linear polymer of D-glucose produced by certain bacterial strains, is classified as a nanomaterial, because the diameter of its single band ranges from 30 to $100 \mathrm{~nm}$. The BC secreted by Gluconoacetobacter xylinus is made up with cellulose I which contains two regions of higher (crystalline) and lower (amorphous) order. The former region forms a network of strong intra and inter-chain hydrogen bonds between the hydroxyl groups of cellulose chains, hence giving high tensile strength to the cellulose. In turn, the less ordered regions are usually available for hydrogen bonding with water; hence, cellulose is able to hold and release water. Cellulose I exists in two different polymorphs, $\mathrm{I}_{\alpha}$ and $\mathrm{I}_{\beta}$. The cellulose chains of $\mathrm{I}_{\alpha}$ and $\mathrm{I}_{\beta}$ are similar in parallel configurations, and their different crystalline structure results from non-identical hydrogen-bond network [11]. The $\mathrm{BC}$ was reported to possess a considerable amount of the $\mathrm{I}_{\alpha}$ allomorph with the ratio $\mathrm{I}_{\alpha} / \mathrm{I}_{\beta}=65 / 35$ [12]. Although cellulose $\mathrm{I}_{\alpha}$ can be converted to the more thermodynamically stable cellulose $\mathrm{I}_{\beta}$ by applying certain treatment processes, for instance by annealing [13], hydrothermal treatment in basic solution $[14,15]$ and high-temperature treatment in organic solvents and helium gas, complete conversion to $\mathrm{I}_{\beta}$ is not achieved [15].

The purpose of this work was to evaluate different conditions of modification of BC with MMT that would lead to the improvement of its functional properties in terms of use as a food packaging material. The effect of MMT addition to disintegrated $\mathrm{BC}$ on the water barrier properties, tensile strength, and thermal stability of the resulting films was studied and the function-structure relationship of these films due to different interactions among their components were analyzed. To our knowledge, the effect of MMT on the properties of composites based on disintegrated $\mathrm{BC}$ has not yet been investigated, although it has been presented in the case of composites based on BC. Due to the complex nature of intra- and inter-molecular interactions in cellulose molecules, for their investigation X-ray diffraction and infrared absorption spectroscopy techniques were used.

\section{Materials and Methods}

\section{BC Production}

Gluconacetobacter xylinus LOCK 89 (Pure Culture Collection of the Institute of Fermentation Technology and Microbiology, Lodz University of Technology, Poland) was used as the microorganism for the $\mathrm{BC}$ production in this study. The number of bacterial cells in the inoculum was approx. $5 \times 10^{7} \mathrm{CFU} / \mathrm{mL}$ [16]. The bacteria were propagated in stationary conditions of growth using a Herstin-Schramm medium, composed of $2 \%(\mathrm{w} / \mathrm{v})$ anhydrous glucose (ACS), $0.27 \%\left(\mathrm{w} / \mathrm{v}\right.$ ) anhydrous $\mathrm{Na}_{2} \mathrm{HPO}_{4}$ (pure P.A), $0.115 \%$ (w/v) monohydrate citric acid (pure P.A) (POCH, Poland), 0.5\% $(\mathrm{w} / \mathrm{v})$ yeast extract (for microbiology), $0.5 \%(\mathrm{w} / \mathrm{v})$ peptone $\mathrm{K}$ (for microbiology) (BTL, Poland), and 1\% (v/v) ethanol (PUH Chemirol, Poland), which was added after sterilization [17]. After 7 days of incubation at $28^{\circ} \mathrm{C}$, the resulting membrane was rinsed in tap water to remove a residual nutrient solution, boiled in a $5 \%(\mathrm{w} / \mathrm{v}) \mathrm{NaOH}$ (pure P.A.) $(\mathrm{POCH}$, Poland) solution for $1 \mathrm{~h}$ to inactivate the bacterial cells, rinsed again in tap water until neutral $\mathrm{pH}$ was reached, and finally shaken $(150 \mathrm{rpm})$ with a distilled water for $1 \mathrm{~h}$. The purified BC membrane, immersed in a distilled water, was sterilized in an autoclave and stored in tightly closed vessels at $4{ }^{\circ} \mathrm{C}$. All membranes thus obtained contained $99.1 \pm 0.1 \%$ water and had similar parameters: a diameter of approx. $20 \mathrm{~cm}$, weight $107.4 \pm 10.4 \mathrm{~g}$ and thickness $3.30 \pm 0.54 \mathrm{~mm}$. In the next step some of them were dried and labelled as the native $\mathrm{BC}$, and some were intended for the film preparation.

\section{Material}

For modification of the BC, MMT-trade name Cloisite $\mathrm{Na}^{+}$(a hydrophilic clay, moisture content 4-9\%, particle size $<13 \mathrm{~mm}$, density $2.86 \mathrm{~g} / \mathrm{mL}$ ), kindly supplied by Southern Clay Products, Inc. (TX, USA) and glycerol (POCH, Poland) were used.

\section{Preparation of Cellulosic Films}

The obtained BC membranes were disintegrated and mixed together with using a homogenizer (MixSy, Zepter, Switzerland) until a paste of homogeneous consistency was obtained, then freeze-dried, and again ground with a homogenizer. From the resulting material (bBC) a 4\% (w/w) suspension in distilled water was prepared and after another homogenization, the suspension was left for $12 \mathrm{~h}$ in a water bath at $28{ }^{\circ} \mathrm{C}$ to allow the cellulose to swell. The homogenization conditions at this stage were always the same (16,000 rpm, $2 \mathrm{~min}$ ).

The MMT was dispersed in a distilled water and stirred with a magnetic stirrer for $24 \mathrm{~h}$ at room temperature, followed by an ultrasound-assisted homogenization $(40 \mathrm{kHz}$, $14,000 \mathrm{rpm}, 15 \mathrm{~min}$ ) by using an ultrasonic bath (SB5200DTD, Shanghai, China) and a homogenizer (Heidolph Instruments D-91126, type Silent CrusherM, Schwabach, Germany).

The dispersion of MMT was homogenized with the bBC suspension for $2 \mathrm{~min}$ at $1600 \mathrm{rpm}$. The final concentration of the $\mathrm{bBC}$ was $2 \%(\mathrm{w} / \mathrm{w})$ and the MMT concentration was 2 or $5 \%(w / w)$ of bBC mass.

Films were prepared manually by casting the prepared suspension on a polyester surface and drying at room temperature. After $24 \mathrm{~h}$ they were covered with a linen fabric to prevent their deformation, and were allowed to dry. 
Selected bBC-based films, both without and with MMT (bBC/MMT), were plasticized with glycerol at a concentration of $10-30 \%(\mathrm{w} / \mathrm{w})$ of substrate mass, which was added to the MMT dispersion before ultrasound-assisted homogenization. The average thickness of the films obtained ranged from 0.20 to $0.23 \mathrm{~mm}$.

\section{Testing of Functional Properties}

\section{Water Vapour Permeability}

Water vapour permeability (WVP) was determined according to the ASTM method E 96-95 [18]. The films were conditioned in a desiccator filled with a saturated solution of $\mathrm{Mg}\left(\mathrm{NO}_{3}\right)_{2}$, whose vapour pressure over the solution corresponds to $50 \%$ relative humidity $(\mathrm{RH})$, for $24 \mathrm{~h}$ at $25{ }^{\circ} \mathrm{C}$ before WVP determination. RH was measured using hygrometer LA8 02/96 (Rotronic). Samples were mounted on cups filled with distilled water, and the cups were placed, at $25{ }^{\circ} \mathrm{C}$ and $50 \% \mathrm{RH}$, in a desiccator. The weight of the cups was measured at $1 \mathrm{~h}$ intervals during $8 \mathrm{~h}$. Simple linear regression was used to estimate the slope of weight loss vs. time plot.

WVP was calculated from the formula:

$W V P=\frac{W V T R \times L}{\Delta p}$,

where water vapour transmission rate $(W V T R)$ is the slope/film area $\left(\mathrm{g} / \mathrm{m}^{2} \times \mathrm{h}\right), L$ is the film thickness $(\mathrm{mm})$, and $\Delta p$ is the partial water vapour pressure difference $(\mathrm{kPa})$ between the two sides of the film. Measurements were performed in at least four replicates, and the average \pm standard deviation was taken as the result.

\section{Mechanical Tests}

Tensile strength $(\sigma)$ and elongation at break $(\varepsilon)$ were determined according to the ASTM method D 882-00 [19] with a model 5543 Instron Universal Testing Machine (Instron Co., Canton, MA, USA). Initial grip separation and crosshead speed were set at $50 \mathrm{~mm}$ and $10 \mathrm{~mm} / \mathrm{min}$, respectively. $\sigma$ was calculated by dividing the maximum load by the initial cross-sectional area of the sample and expressed in MPa. $\varepsilon$ was calculated as a ratio of the elongation at the point of sample rupture to the initial length of a sample as a percentage. Strips of films (15 $\mathrm{mm}$ by $100 \mathrm{~mm}$ ) were conditioned for $48 \mathrm{~h}$ at $25{ }^{\circ} \mathrm{C}$ and $50 \% \mathrm{RH}$ before $\sigma$ and $\varepsilon$ determination. At least ten replicates were tested for each film and the average \pm standard deviation was taken as the result.

\section{Testing of Morphological, Thermal and Structural Properties}

\section{Scanning Electron Microscopy (SEM)}

High resolution field emission gun (FEG) scanning electron microscopy images were collected using VERSA 3D DualBeam (FEI Company, Hillsboro, OR). The instrument set for $5 \mathrm{kV}$ accelerating voltage and 1.6 or $3.3 \mathrm{pA}$ beam current, was operated at high-vacuum. The magnification range changed from 500 to 20000 times. To observe the cross-sections, the samples were glued with carbon tape to a carbon steel cube.

\section{Thermal Analysis (TG and DTG)}

Thermogravimetric analysis was performed using the TA Instrument SDT Q600 (New Castle, DE). The samples of 10-20 mg were heated in open aluminium pans under dynamic nitrogen atmosphere within temperature range of $40-800{ }^{\circ} \mathrm{C}$, at heating rate of $10^{\circ} \mathrm{C} / \mathrm{min}$. Before analysis all samples were conditioned for 7 days over $\mathrm{P}_{2} \mathrm{O}_{5}$ in desiccators to remove residual moisture.

\section{X-ray Diffractometry (XRD)}

To study the crystal structure of samples, the X-ray diffraction patterns were recorded in a Philips type X'Pert Pro diffractometer (Eindhoven, The Netherlands) by using $\mathrm{CuK} \alpha$ radiation at $30 \mathrm{~mA}$ and $40 \mathrm{kV}$. The spectra over the range of $0^{\circ}-60.0^{\circ} 2 \theta$ were recorded at scan rate of $0.02^{\circ} 2 \theta / \mathrm{s}$.

The crystallinity index (Cr.I.) was determined by the equation proposed by Segal [20]:

$$
\text { Cr.I. }=\frac{\left(I_{200}-I_{a m}\right)}{I_{200}} \times 100
$$

where $I_{200}$ and $I_{\text {am }}$ are the maximum intensities of diffraction at $2 \theta=22^{\circ}, 7^{\circ}$ and $18^{\circ}$, respectively.

The ratio of cellulose allomorph $\mathrm{I}_{\alpha}$ to $\mathrm{I}_{\beta}\left(\mathrm{I}_{\alpha} / \mathrm{I}_{\beta}\right)$ was determined as the ratio of the peak area at $14.6^{\circ}$ and $22.6^{\circ} 2 \theta$, respectively.

\section{Attenuated Total Reflectance Fourier Transform Infrared Spectroscopy (ATR FT-IR)}

The ATR FT-IR spectra of samples were recorded on Nicolet 8700 spectrophotometer (Thermo Electron Scientific Inc., Waltham, MA), using a Golden Gate ATR accessory (Specac) equipped with a single-reflection diamond crystal. The temperature during measurements was kept at $25 \pm 0.1{ }^{\circ} \mathrm{C}$ using an electronic temperature 
controller (Specac). For each spectrum, 128 scans were collected in the range of 500 to $4000 \mathrm{~cm}^{-1}$, with resolution of $4 \mathrm{~cm}^{-1}$. The spectrometer's EverGlo source was on turbo mode during measurements. The spectrometer and ATR accessory were purged with dry nitrogen to diminish water-vapour contamination of the spectra. All samples were conditioned before their analysis for 7 days in a desiccator over $\mathrm{P}_{2} \mathrm{O}_{5}$. For each sample aliquot, three to five replicate spectra were recorded to assess precision and ensure the reproducibility of each sample.

Second derivatives of the spectra were calculated by using the Savitzky-Golay algorithm (27 data points, ca. $25 \mathrm{~cm}^{-1}$, and a 3rd degree polynomial) in order to resolve the overlapping bands of individual vibrations in the region $3600-3000 \mathrm{~cm}^{-1}$.

To study the crystallinity changes, total crystallinity index (TCI) [21], lateral order index (LOI) [22], and hydrogen bond intensity (HBI) [23], calculated from the absorbance ratios $\mathrm{A}_{1372} / \mathrm{A}_{2897}, \mathrm{~A}_{1430} / \mathrm{A}_{893}$, and $\mathrm{A}_{3336} / \mathrm{A}_{1336}$, respectively, were used.

The ratio of cellulose allomorph $\mathrm{I}_{\alpha}$ to $\mathrm{I}_{\beta}\left(\mathrm{I}_{\alpha} / \mathrm{I}_{\beta}\right)$ was calculated by the following equations [24]:

$$
\begin{aligned}
& A_{\alpha}=A_{750}-A_{800} \\
& A_{\beta}=A_{710}-A_{800} \\
& f_{\alpha}^{I R}=\frac{A_{\alpha}}{\left(A_{\alpha}+A_{\beta}\right)} \\
& f_{\alpha}=2.55 f_{\alpha}^{I R}-0.32 \\
& \frac{\alpha}{\beta}=\frac{f_{\alpha}}{\left(1-f_{\alpha}\right)}
\end{aligned}
$$

where $A_{\alpha}$, and $A_{\beta}$ are the integrated intensities of the contributions from celluloses $I_{\alpha}$ and $I_{\beta}$, respectively, $f_{\alpha}^{I R}$ is an apparent mass fraction of cellulose $I_{\alpha}$ and $f_{\alpha}$ is the mass fraction of cellulose $I_{\alpha}$.

\section{Statistical Analysis}

The results listed in tables are averages from four to ten replications \pm standard deviation. Data were evaluated by analysis of variance (one-way procedure) using SigmaPlot 11.0 (Softonic International S.L). Differences between the means were determined by Tukey test $(\mathrm{P}<0.05)$.

\section{Results and Discussion}

\section{Functional Properties}

\section{Water Barrier Properties}

The WVP of the native $\mathrm{BC}$ was $0.055 \mathrm{~g} \cdot \mathrm{mm} \cdot \mathrm{kPa}^{-1} \cdot \mathrm{h}^{-1} \cdot \mathrm{m}^{-2}$. Padrão et al. [25] noted 2 times higher WVP. However, the WVP of bacterial cellulose varies depending on the culture conditions, sample moisture content, the way of $\mathrm{BC}$ preparation for measurements, and finally the measurement conditions (temperature, $\mathrm{RH}$ ) [26-28]. The obtained WVP value was more than 6 times lower than that obtained for the $\mathrm{bBC}$ (Table 1). As the nanofibers of the $\mathrm{BC}$ were expected to be damaged during grinding because of high shearing and compression forces used in this method, the bBC had a less homogeneous surface than the BC. This probably allowed the water vapour to penetrate more freely through the $\mathrm{bBC}$ than through the BC. In the presence of glycerol, a reduction of WVP in comparison to that of unplasticized bBC was observed (Table 1). The observed dependence seems unusual, because the presence of a plasticizer in biopolymerbased materials, including polysaccharide-based films, generally increases their WVP [29]. According to Cazón et al. [30], plasticization of bacterial cellulose films with glycerol at concentration of $2.5 \%$ resulted in a 2.5 -fold increase in WVP, and at concentration of 5\% glycerol-in almost fourfold increase. Nevertheless, Ghanbarzadeh et al. [31] noted that the addition of $50-70 \%$ glycerol decreased WVP of in zein films by $40 \%$. According to these authors, the reduced value of WVP resulted from the higher surface homogeneity of the films due to their plasticization.
Table 1 Effect of the concentration of montmorillonite (MMT)

\begin{tabular}{|c|c|c|c|c|}
\hline \multirow[t]{2}{*}{$\operatorname{MMT}(\%)^{* *}$} & \multicolumn{4}{|l|}{ Glycerol (\%)** } \\
\hline & 0 & 10 & 15 & 30 \\
\hline 0 & $0.366 \pm 0.031^{\mathrm{bA}}$ & $0.290 \pm 0.035^{\mathrm{bAB}}$ & $0.288 \pm 0.035^{\mathrm{bAB}}$ & $0.279 \pm 0.011^{\mathrm{aB}}$ \\
\hline 2 & $0.418 \pm 0.045^{\mathrm{bA}}$ & $0.342 \pm 0.084^{\mathrm{bAB}}$ & $0.289 \pm 0.022^{\mathrm{bAB}}$ & $0.226 \pm 0.031^{\mathrm{aB}}$ \\
\hline 5 & $0.595 \pm 0.063^{\mathrm{aA}}$ & $0.513 \pm 0.068^{\mathrm{aAB}}$ & $0.456 \pm 0.040^{\mathrm{aAB}}$ & $0.314 \pm 0.053^{\mathrm{aB}}$ \\
\hline
\end{tabular}
and glycerol on the Water Vapour Permeability (WVP, $\left.\mathrm{g} \cdot \mathrm{mm} \cdot \mathrm{kPa}^{-1} \mathrm{~h}^{-1} \mathrm{~m}^{-2}\right)^{*}$ of bBCbased films
*Mean value of 4 determinations \pm standard deviation. Different superscript letters $(a-b)$ within the same column indicate significant differences due to the addition of MMT $(\mathrm{P}<0.05)$. Different superscript letters (A-B) within the same row indicate significant differences due to the addition of glycerol $(\mathrm{P}<0.05)$

$* *$ Concentration relative to $\mathrm{bBC}$ mass $(\mathrm{w} / \mathrm{w})$ 
The addition of $2 \%$ of MMT did not affect the WVP value of the bBC, while the $5 \%$ addition increased it by approx. $60 \%$ (Table 1). The deterioration of the water barrier properties of materials based on hydrophilic polymers may be due to the hydrophilic nature of the clay mineral. Staroszczyk et al. [32] also observed about 23\% higher WVP value for starch films with the addition of $5 \%$ of MMT than for films without MMT. According to Martucci et al. [33], the deterioration of the water barrier properties of the gelatine-based nanocomposites due to the addition of $10 \%$ of MMT could also result from insufficient dispersion of the MMT in the polymer matrix. Thus, the 5\% content of MMT in the bBC-based films could be too high and the MMT particles agglomerated in the polymer structure, even though the homogenization of MMT suspension was performed before formation of the films.

In the presence of glycerol, in composite films based on the bBC with 2 and $5 \%$ of MMT, a trend of decreasing WVP values with increasing concentration of glycerol was observed, analogous to the case with the addition of glycerol to bBC without MMT (Table 1). According to Vieira et al. [29], glycerol, as a small molecule compound, diffusing into the polymer, reduces the intermolecular interactions between its chains, thus, facilitating the migration of water vapour molecules through its matrix. Moreover, as a hydrophilic compound, glycerol increases the sorption of water by films, thereby deteriorating their water vapour barrier. Although glycerol by itself improved the barrier properties of the bBC to water vapour, an improvement of barrier properties of the bBC with MMT with increasing concentration of glycerol could also result from the formation of hydrogen bonds network in the bBC structure in the presence of glycerol.

\section{Mechanical Properties}

Tensile strength of the native $\mathrm{BC}$ was $63.5 \mathrm{MPa}$, i.e. 2 times higher than $\sigma$ of the bBC (Table 2). Like the deterioration of water vapour barrier properties, the decrease in tensile strength of the $\mathrm{BC}$ due to disintegration of its membranes was probably caused by the less homogeneous surface of the bBC. According to Gea et al. [5], when the BC membranes are mechanically fragmented prior to preparing sheets, the tensile strength of the products is decreased, what is attributed to the loss of continuity in the original network structure $[5,34,35]$.

The addition of a plasticizer usually leads to reduction of the $\sigma$ value of films, and the higher the concentration of glycerol used, the lower $\sigma$ is [36]. The bBC in the presence of $10 \%$ glycerol did not show significant changes in $\sigma$, while that in the presence of 15 and $30 \%$ glycerol had $\sigma$ reduced by approx. 60 and 50\%, respectively (Table 2 ).

The addition of $2 \%$ of MMT to the bBC resulted in an increase of $\sigma$ by ca. $15 \%$, and the addition of $5 \%$ of MMTin a reduction by ca. $8 \%$. (Table 2). Although these differences were not statistically significant, the observed changes are consistent with the reports of many authors. The increase in the tensile strength of nanocomposites is possible only to a certain limit of the filler concentration, above which $\sigma$ is reduced [8, 37-39]. For example, Giannakas et al. [37] observed an increase in $\sigma$ of chitosan films with a 3 and 5\% of MMT addition by ca. 70 and $20 \%$, respectively, while $10 \%$ addition of MMT did not affect $\sigma$ anymore. The insignificant drop of $\sigma$ in films with high concentration of MMT may be due to a reduction in the number of interactions between the bBC and MMT, in favour of increased interactions between the clay mineral, which results in agglomeration of its molecules [33].

In the case of plasticized bBC/MMT films, a significant reduction of $\sigma$ was observed only in the presence of $30 \%$
Table 2 Effect of the concentration of montmorillonite (MMT) and glycerol on mechanical parameters of bBC-based films

\begin{tabular}{|c|c|c|c|c|}
\hline \multirow[t]{2}{*}{ MMT (\%)* } & \multicolumn{4}{|l|}{ Glycerol (\%)* } \\
\hline & 0 & 10 & 15 & 30 \\
\hline \multicolumn{5}{|l|}{$\sigma(\mathrm{MPa}) * *$} \\
\hline 0 & $31.2 \pm 2.9^{\mathrm{a}, \mathrm{b}, \mathrm{cA}}$ & $31.1 \pm 2.1^{\mathrm{aA}}$ & $12.1 \pm 1.5^{\mathrm{bC}}$ & $14.7 \pm 2.0^{\mathrm{bB}}$ \\
\hline 2 & $35.6 \pm 2.0^{\mathrm{a}, \mathrm{bA}}$ & $31.9 \pm 3.1^{\mathrm{aB}}$ & $30.7 \pm 1.7^{\mathrm{aB}}$ & $18.1 \pm 1.5^{\mathrm{aC}}$ \\
\hline 5 & $28.7 \pm 2.6^{\mathrm{b}, \mathrm{cB}}$ & $33.4 \pm 3.2^{\mathrm{aA}}$ & $31.9 \pm 4.1^{\mathrm{aA}}$ & $19.2 \pm 1.8^{\mathrm{aC}}$ \\
\hline \multicolumn{5}{|l|}{$\varepsilon(\%)^{* *}$} \\
\hline 0 & $3.26 \pm 0.70^{\mathrm{aA}}$ & $3.17 \pm 0.27^{\mathrm{aAB}}$ & $1.02 \pm 0.17^{\mathrm{cC}}$ & $2.37 \pm 0.36^{\mathrm{aB}}$ \\
\hline 2 & $3.46 \pm 0.52^{\mathrm{aA}}$ & $3.58 \pm 0.53^{\mathrm{aAB}}$ & $3.08 \pm 0.52^{\mathrm{bA}}$ & $2.27 \pm 0.48^{\mathrm{aB}}$ \\
\hline 5 & $3.52 \pm 0.75^{\mathrm{aB}}$ & $3.63 \pm 0.63^{\mathrm{aAB}}$ & $4.27 \pm 0.71^{\mathrm{aA}}$ & $1.80 \pm 0.35^{\mathrm{bC}}$ \\
\hline
\end{tabular}


glycerol. On the other hand, the addition of MMT in the both concentrations used ( 2 and $5 \%$,), in the presence of 15 and $30 \%$ glycerol increased $\sigma$ of the bBC-based films by ca. 150 and $30 \%$, respectively (Table 2 ). Such improvement of the mechanical strength of nanocomposites in the presence of glycerol, as the effect of reducing their WVP, probably results from extra hydrogen bonds between their components.

The elongation of the native $\mathrm{BC}$ was $3.1 \%$, and both disintegration of its membranes and plasticization of the $\mathrm{bBC}$ did not improve this feature. The $\varepsilon$ value of all bBC-based films, both unplasticized and plasticized with glycerol, was low, ranging between 1 and $4 \%$ (Table 2).

\section{Morphological, Thermal and Structural Properties}

\section{Morphological Properties}

Microscopic observations confirmed that, as a result of $\mathrm{BC}$ membrane disintegration and modification of the $\mathrm{bBC}$ with MMT, the morphology of the film surface becomes less homogeneous and its structure non-layered (Fig. 1). While the SEM image of native BC revealed a coherent 3D network of cellulose fibers forming a uniform surface (Fig. 1a) and a layered structure (Fig. 1b), the surface of the $\mathrm{bBC}$ and $\mathrm{bBC} / \mathrm{MMT}$ was heterogeneous and rough (Fig. 1c, e), and their structure showed no distinct layers (Fig. 1d, f). There were no significant changes in the morphology of the material when MMT was added to the bBC, MMT particles were not visible, neither on surface (Fig. 1e) nor cross-section (Fig. 1f) of bBC/MMT. Moreover, the $\mathrm{bBC}$ surface was more compact, the individual fibres were invisible, but single pores were larger than those in native $\mathrm{BC}$ and, additionally, they were unevenly distributed. Ul-Islam et al. [40] noted a similar effect, by testing the $\mathrm{BC}$ films dried in various conditions. According to the authors, larger pores in $\mathrm{BC}$-based materials contribute to easier water penetration, and consequently, to the reduction in their tensile strength. Thus, disintegration of BC membranes and modification of the bBC with MMT affected morphology of the film surface, resulting in the increase in WVP (Table 1) and the decrease in $\sigma$ (Table 2) of the films. In the case of plasticized films, both the surface (Fig. 1g) and the cross-section (Fig. 1h) images indicated smoother and more homogeneous material than that of unplasticized films. The pores were small and hardly visible in that material. These observations are in agreement with Ghanbarzadeh et al. [31]. According to these authors, plasticization of the biopolymer allows to obtain more uniform film matrix, because the plasticizer increases the association of polymer chains.

\section{Thermal Properties}

As the addition of 5\% of MMT did not improve the mechanical and water barrier properties of the bBC-based films, thermal and structural properties of only those with the addition of $2 \%$ of MMT (bBC/MMT) without and in the presence of 10 and $15 \%$ glycerol, bBC/MMT/G10 and bBC/MMT/G15, respectively, were investigated.

A fast, one-step decomposition of the BC took place at $363{ }^{\circ} \mathrm{C}$ (Fig. 2) with a loss of $84 \%$ of its weight within the range $200-400{ }^{\circ} \mathrm{C}$ (Table 3). The disintegration of the $\mathrm{BC}$ reduced that weight loss by almost $30 \%$. Besides, the slope of the TG line expressed in terms of $\operatorname{tg} \alpha$ turned milder. Thus, it seems that thermal stability of the $\mathrm{BC}$ increases due to disintegration of its membranes, even though the degradation temperature remained unchanged.

The MMT showed a very high thermal stability, as the total weight loss up to $790{ }^{\circ} \mathrm{C}$ was only $5.03 \%$. This small percentage was due to the desorption of free water and water from the interlayer space occurring within the range $20-200{ }^{\circ} \mathrm{C}$, and the release of dehydroxylated $\mathrm{OH}-$ groups (the structural water) taking place within the range $400-790{ }^{\circ} \mathrm{C}$ [41].

The addition of $2 \%$ of MMT did not significantly affect neither the weight loss nor the degradation temperature of the $\mathrm{bBC}$, and the pattern of the thermogram remained essentially the same. Some published data show an improvement of the thermal stability of polymer-based materials with addition of MMT [42-44]. According to Park et al. [44] such an effect is a result of the high dispersion of nanofiller particles in the polymer matrix. Cyras et al. [43] also noted that the MMT, as an inorganic material, has higher thermal stability than a polymer constituent of films. However, Sinha et al. [42] reported that with increasing temperature, the nanofiller particles get hot, becoming an additional source of heat inside the nanocomposite structure and thus accelerating its degradation.

In the presence of $10 \%$ glycerol, the bBC/MMT films lost within the temperature range $50-200{ }^{\circ} \mathrm{C}$ ca. 4-times more, and in the presence of $15 \%$ glycerol, 2-times more weight than films without glycerol. On the DTG curve obtained for these films, additional endothermic peaks at $186{ }^{\circ} \mathrm{C}$ in the case of films with $10 \%$, and at $193{ }^{\circ} \mathrm{C}$ in the case of films with $15 \%$ glycerol, were observed (Table 3). Garcia et al. [45] also observed an increase in weight losses in the temperature range of $80-280{ }^{\circ} \mathrm{C}$ and a decrease in the temperature of degradation of starch films due to the plasticization with glycerol. According to Lavorgna et al. [22], the weight loss within the range of $50-150{ }^{\circ} \mathrm{C}$ results from thermal degradation of unbound plasticizer molecules. An insight in Table 4 revealed that the $\mathrm{bBC} / \mathrm{MMT}$ in the presence of 10 and $15 \%$ of glycerol showed a slight increase in a weight loss in the temperature 
Fig. 1 SEM images of the native $\mathrm{BC}$ and $\mathrm{bBC}$-based films
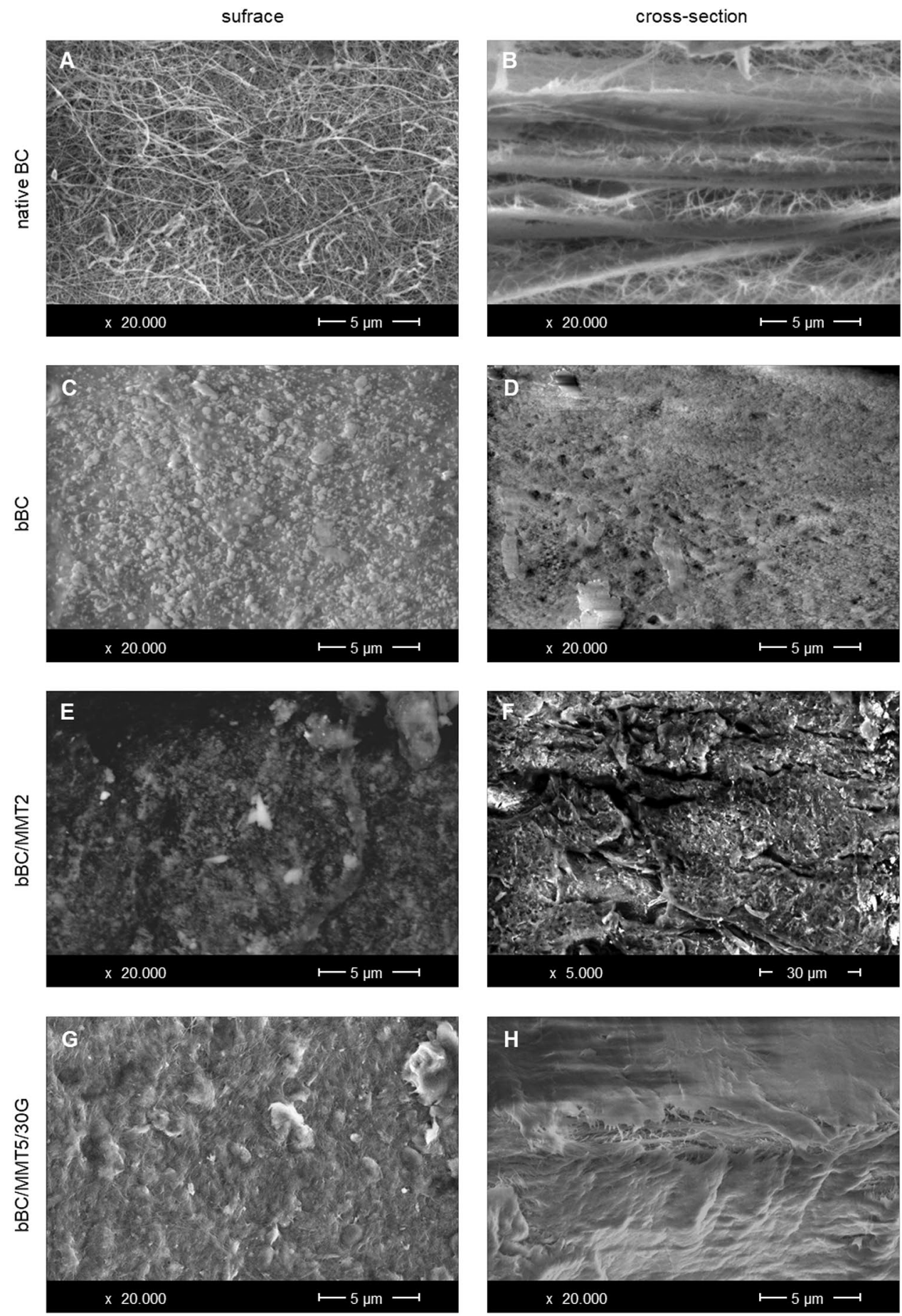

range of $200-400{ }^{\circ} \mathrm{C}$. Moreover, based on the slope of TG line, the plasticized films decomposed with a higher rate than those unplasticized. According to Cyras et al. [43], plasticization of polymeric films reduces the number of inter- and intramolecular interactions between the polymer chains. The loosening of the material structure leads to easier degradation of the polymer. This degradation is the easier (the faster), the higher plasticizer concentration is used [43].
Nevertheless, the thermal stability of all the bBC/MMT films, both unplasticized and plasticized with glycerol, was higher than that of the $\mathrm{BC}$; although the degradation temperature of these films did not change in most cases, they decomposed more slowly than the $\mathrm{BC}$, and their weight loss during heating in the temperature range of $50-690{ }^{\circ} \mathrm{C}$ was lower in average by $17 \%$. 

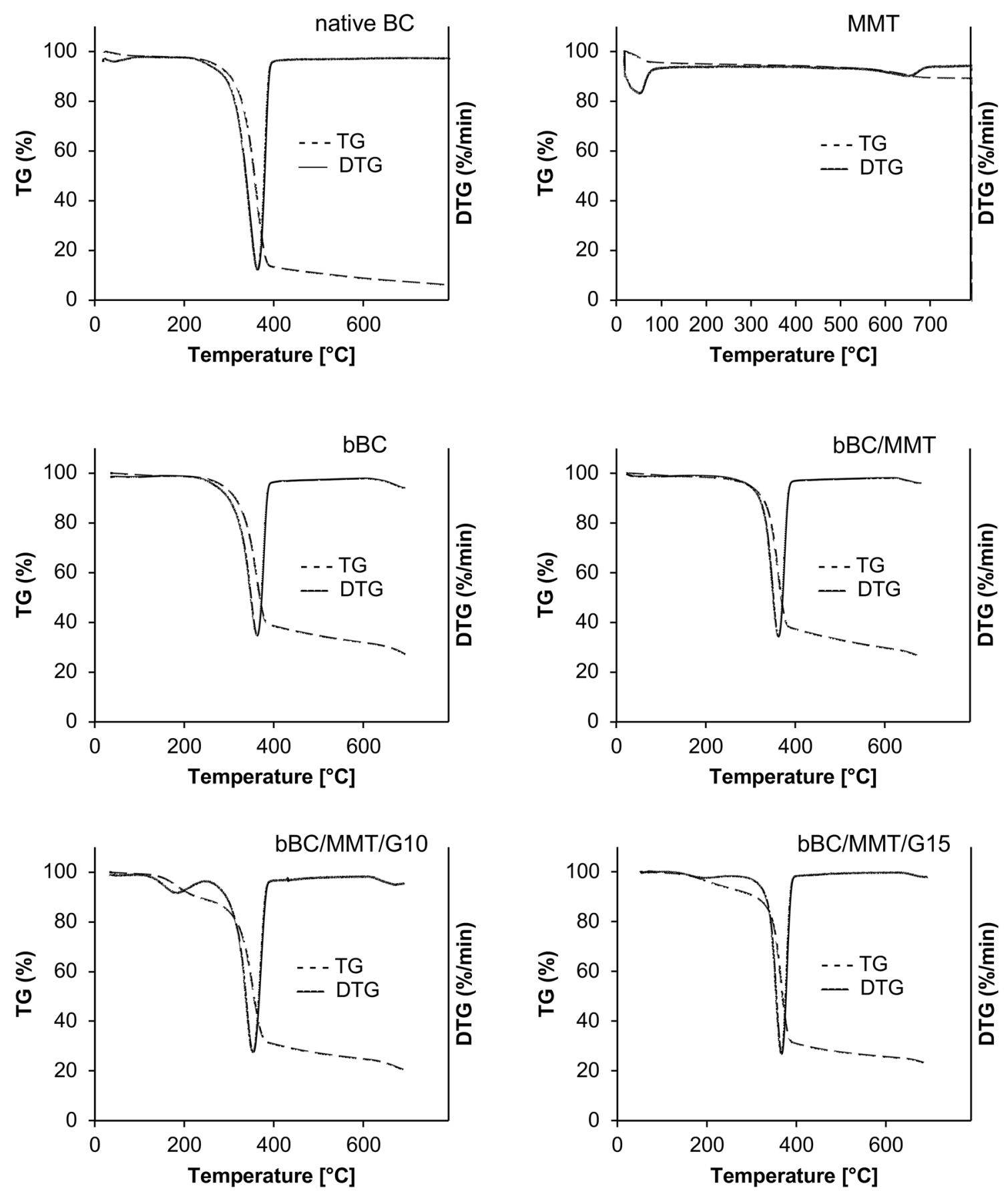

Fig. 2 Thermograms of the native BC, MMT and bBC-based films

\section{Crystalline Properties}

In the diffraction pattern of the BC, two sharp intense peaks at $14.6^{\circ}$ and $22.6^{\circ} 2 \theta$ (Fig. 2), assigned to $\mathrm{I}_{\alpha}$ and $\mathrm{I}_{\beta}$ crystalline, respectively [36], were observed. The diffraction patterns of all other films obtained remained essentially the same, but unlike in that observed in the BC, in

those present in bBC-based films, the former peak was lower, and the latter significantly higher (Fig. 3, Table 4).

The Cr.I. of the BC was high, but that of bBC-based films, both plasticized and unplasticized, was higher by approx. 5\% (Table 4). The observed effect of increasing crystallinity due to disintegration of the $\mathrm{BC}$ membrane is opposite to the effect reported by other authors. According to Yousefi 
Table 3 Thermogravimetric characteristics of the native $\mathrm{BC}$, montmorillonite (MMT) and bBC-based films

\begin{tabular}{|c|c|c|c|c|}
\hline Film & $\begin{array}{l}\text { Temperature range } \\
\left({ }^{\circ} \mathrm{C}\right)\end{array}$ & Weight loss $(\%)^{*}$ & Slope $(\operatorname{tg} \alpha)^{* *}$ & DTG $\left({ }^{\circ} \mathrm{C}\right)$ \\
\hline \multirow[t]{4}{*}{$\mathrm{BC}$} & $50-200$ & 1.57 & 6.9 & \\
\hline & $200-400$ & 84.09 & & 363 \\
\hline & $400-690$ & 5.86 & & \\
\hline & Total & 91.52 & & \\
\hline \multirow[t]{4}{*}{$\mathrm{bBC}$} & $50-200$ & 1.23 & 5.6 & \\
\hline & $200-400$ & 60.03 & & 362 \\
\hline & $400-690$ & 11.01 & & \\
\hline & Total & 72.27 & & \\
\hline \multirow[t]{4}{*}{ bBC/MMT } & $50-200$ & 1.44 & 6.1 & \\
\hline & $200-400$ & 61.07 & & 361.6 \\
\hline & $400-690$ & 11.28 & & \\
\hline & Total & 73.8 & & \\
\hline \multirow[t]{4}{*}{ bBC/MMT/G10 } & $50-200$ & 7.27 & 6.2 & 185.8 \\
\hline & $200-400$ & 61.65 & & 353 \\
\hline & $400-690$ & 10.28 & & \\
\hline & Total & 79.19 & & \\
\hline \multirow[t]{4}{*}{ bBC/MMT/G15 } & $50-200$ & 3.71 & 6.4 & 192.9 \\
\hline & $200-400$ & 65.32 & & 366.4 \\
\hline & $400-690$ & 7.92 & & \\
\hline & Total & 76.94 & & \\
\hline \multirow[t]{4}{*}{ MMT } & $20-200$ & 5.13 & & 50.1 \\
\hline & $200-400$ & 0.68 & & \\
\hline & $400-790$ & 4.77 & & 648 \\
\hline & Total & 5.03 & & \\
\hline
\end{tabular}

*Percentage of weight loss during the special temperature ranges

**The slope of TG line
Table 4 The crystalline properties of bBC-based films

\begin{tabular}{lllllll}
\hline Film & Cr.I & $\mathrm{I}_{\alpha} / \mathrm{I}_{\beta}{ }^{*}$ & $\mathrm{I}_{\alpha} / \mathrm{I}_{\beta}{ }^{* *}$ & TCI & LOI & HBI \\
\hline BC & 86.1 & 1.24 & 1.41 & 1.06 & 1.14 & 1.90 \\
bBC & 90.3 & 0.70 & 0.89 & 1.25 & 1.18 & 1.17 \\
bBC/MMT & 90.0 & 0.46 & 1.09 & 1.16 & 0.93 & 1.30 \\
bBC/MMT/G10 & 90.1 & 0.57 & 0.95 & 1.40 & 1.12 & 1.01 \\
bBC/MMT/G15 & 90.9 & 0.49 & 1.26 & 1.69 & 1.42 & 0.93 \\
\hline
\end{tabular}

*Calculated based on the surface area of peaks on XRD patterns

**Calculated based on the intensity of bands on FTIR spectra et al. [34], grinding of cellulose had a significant impact on the loss of crystallinity, which is due to the high shearing and pressure forces created during grinding. However, the proportion of the $I_{\alpha}$ crystalline form decreased, and that $I_{\beta}$ increased because of the disintegration of BC membranes as shown by the $\mathrm{I}_{\alpha} / \mathrm{I}_{\beta}$ ratio calculated based on the surface area under the peaks at $14.6^{\circ}$ and $22.6^{\circ} 2 \theta$ respectively (Table 4 ). Since the difference between $\mathrm{I}_{\alpha}$ and $\mathrm{I}_{\beta}$ results from non-identical network of hydrogen-bonds in both forms, the change in the ratio of both allomorphs was probably influenced by the change in intra- and intermolecular hydrogen bonding in the BC structure, which affected the change in the crystallinity degree.

The addition of $2 \%$ of MMT and 10 or $15 \%$ of glycerol did not significantly affect the degree of bBC crystallinity (Table 4). According to Ul-Islam et al. [8], the decrease of the number of intramolecular hydrogen bonds in the $\mathrm{BC}$ due to an increased interaction of the matrix with nanofiller particles reduces the degree of crystallinity, while Cyras et al. [43] believe that the degree of crystallinity of starch films decreases with increasing plasticiser concentration due to the reduction of interactions between matrix chains. No 
Fig. 3 Diffractograms of the native $\mathrm{BC}$ and $\mathrm{bBC}$-based films

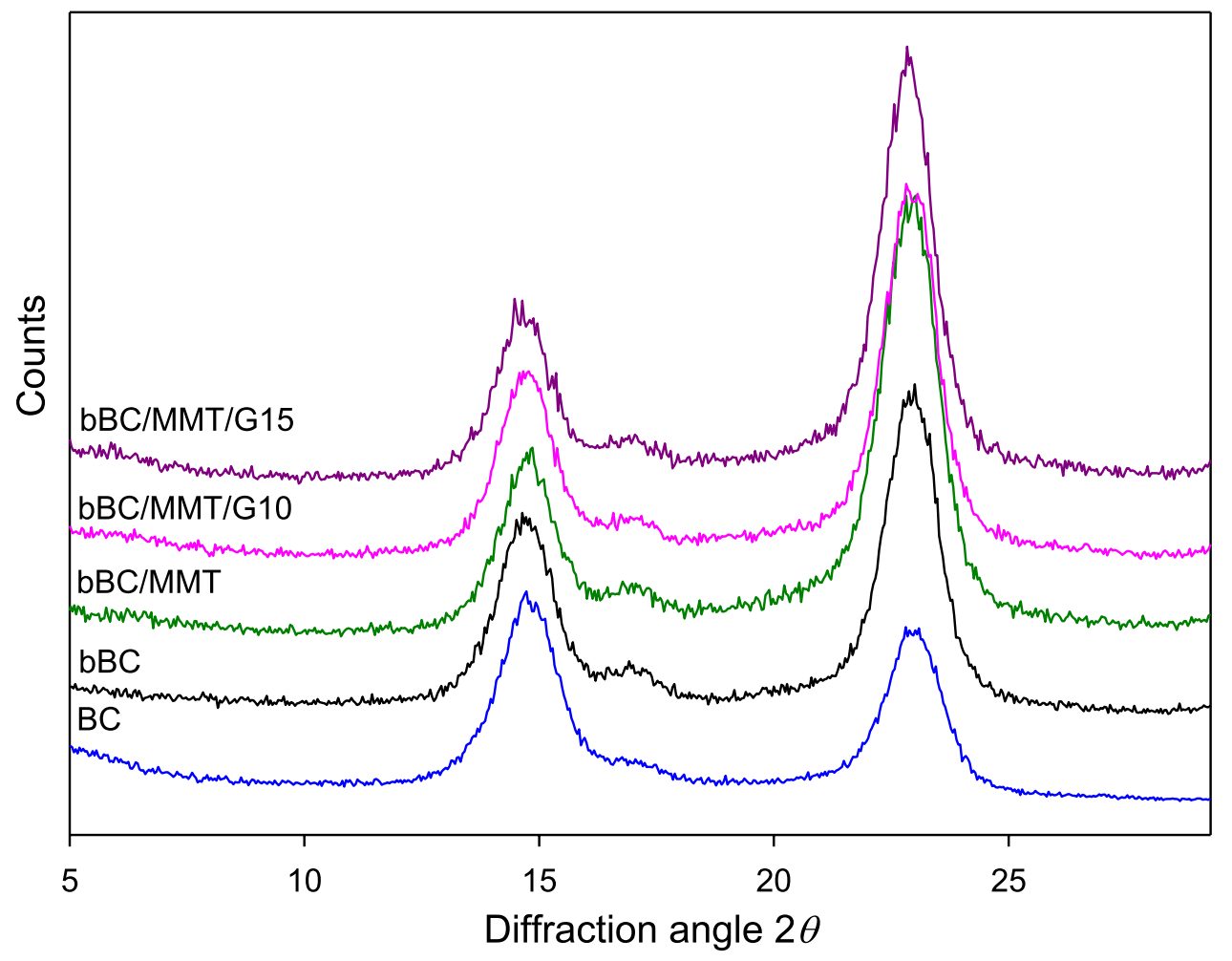

decrease of crystallinity degree was observed in the films studied and the Cr.I. seems to confirm the previous results, determined by the analysis of barrier, mechanical and thermal properties, which indicate the formation of structure strengthening bonds of bBC-based films.

\section{Chemical Structure}

The FTIR spectra of the $\mathrm{BC}$ and $\mathrm{bBC}$-based films are presented in Fig. 4, and the vibration bands of the particular functional groups [8, 46-51] are listed in Table 5.

The spectra of all bBC-based films displayed the same characteristic bands as the spectrum of the $\mathrm{BC}$; however, the position and intensity of absorption bands in the individual spectra slightly differed.

Comparing the bBC spectrum with that of BC (Fig. 4a), the decrease of absorption in the region between 3600 and $3000 \mathrm{~cm}^{-1}$, with one negative peak appearing at $3350 \mathrm{~cm}^{-1}$ in the difference spectrum, and the slight increase of absorbance at 3300 and $3245 \mathrm{~cm}^{-1}$, were observed. All these bands are assigned to $\mathrm{O}-\mathrm{H}$ stretching vibrations $\left(\nu_{\mathrm{OH}}\right)$. Changes in the bonding of $\mathrm{OH}$ groups resulted in a shift by $6 \mathrm{~cm}^{-1}$ in the maximum of the band centered at $3346 \mathrm{~cm}^{-1}$ in the $\mathrm{BC}$ spectrum towards lower wavenumbers in the spectrum of the $\mathrm{bBC}$. These changes were confirmed by the analysis of the second-derivative spectra. The used procedure enabled to resolve the band at the $3600-3000 \mathrm{~cm}^{-1}$ region into its four component bands, at $3407,3348,3290$, and $3235 \mathrm{~cm}^{-1}$
(Fig. 5). All these bands were shifted by $2-6 \mathrm{~cm}^{-1}$ towards lower wavenumbers in the spectrum of the $\mathrm{bBC}$. The former pair of bands was due to intramolecular hydrogen bonds between $\mathrm{OH}$ group at the $\mathrm{C}-3$ and $\mathrm{C}-5$ position, and at the C-2 and C-6 position of the adjacent glucose ring, and the latter pair of bands was due to intermolecular hydrogen bonds between $\mathrm{OH}$ group at the C- 6 position and C-3' O atom of the D-glucose ring of the adjacent polysaccharide chain [51, 52]. All changes observed in the analyzed band indicated the scission of intramolecular hydrogen bonds between the $\mathrm{OH}$ groups in the $\mathrm{BC}$ due to the disintegration of its membranes, which at the same time increased the potential for forming intermolecular hydrogen bonds in the bBC. It seems that the possibility for hydrogen bonding between hydroxyl D-glucose units of the adjacent cellulose chains could attribute to the higher degree of crystallinity and thermal stability of the bBC (Table 3).

The decrease of absorbance at $2897 \mathrm{~cm}^{-1}$, with one negative peak appearing at $2918 \mathrm{~cm}^{-1}$ in the difference spectrum, assigned to $\nu_{\mathrm{CH}}$, and the increase in the absorbance of the $1450-1350 \mathrm{~cm}^{-1}$, with one positive peak occurring at $1410 \mathrm{~cm}^{-1}$ in the difference spectrum (Fig. 4a), corresponding to bending vibrations of $\mathrm{C}-\mathrm{H}$ bonds $\left(\delta_{\mathrm{CH}}\right)$, were also observed. These changes could be attributed to conformation changes of cellulose chains, resulting from greater freedom of movement of $\mathrm{OH}$ groups when intramolecular hydrogen bonds were broken [53]. The increase in the band intensity in the $1450-1350 \mathrm{~cm}^{-1}$ range, on the one hand is related to 
the formation of an intermolecular hydrogen bond involving $6 \mathrm{C}-\mathrm{OH}$ [53], and on the other hand is associated with increasing the degree of crystallinity of the film [54]. These findings are confirmed by the results obtained from the XRD analysis (Table 5).

There was also an additional band centered at $870 \mathrm{~cm}^{-1}$ in the spectrum of the bBC (Fig. 4a), confirmed by a positive peak located at the same wavenumber in the differential spectrum. This band was absent in the spectrum of the BC. According to Oh et al. [51], it corresponds to deformation vibrations in $\beta$-glycosidic bonds. However, the $950-750 \mathrm{~cm}^{-1}$ region usually corresponds to the anomeric region and is characteristic of the saccharide configurations. As reported by Parker [55], $\alpha$-D anomers display a band at
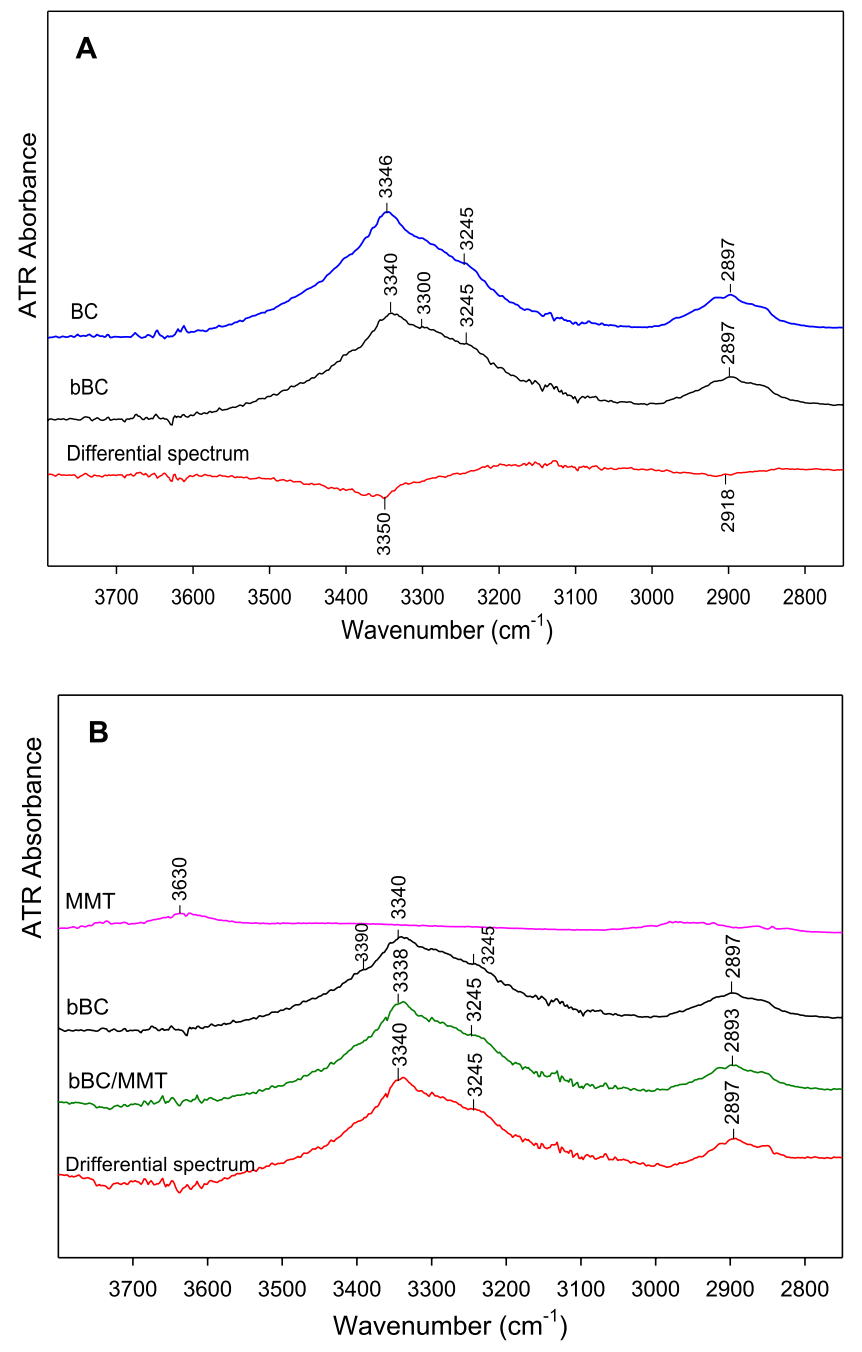

Fig. 4 FT-IR spectra of bBC-based films: a differential spectrum of $\mathrm{bBC}$ after the spectrum of $\mathrm{BC}$ was subtracted (red line), spectra of $\mathrm{BC}$ (blue line) and bBC (black line) are shown for comparison; b differential spectrum of $\mathrm{bBC} / \mathrm{MMT}$ after the spectrum of MMT was subtracted (red line), spectra of MMT (pink line), bBC (black line), and $\mathrm{bBC} / \mathrm{MMT}$ (green line) are shown for comparison; c differential spectrum of bBC/MMT/G10 after the spectrum of glycerol was sub-
$840 \mathrm{~cm}^{-1}$, and $\beta$-D anomers at $890 \mathrm{~cm}^{-1}$, both types originating from the anomeric $\mathrm{C}-\mathrm{H}$ deformation (Table 5). It can be therefore assumed that during the $\mathrm{BC}$ disintegration not only intramolecular hydrogen bonds were broken but probably glycoside bonds too, as evidenced by the appearance in the $\mathrm{bBC}$ spectrum of the band attributed to the $\beta$-anomeric carbon. The scission of these bonds, and the resulting reorganization of the $\mathrm{BC}$ structure due to the dispersion of its membranes, probably contributed to the increase of WVP and reduction of the tensile strength of bBC-based films.

The analysis of FTIR spectra also enables the comparison of the content of allomorphs $\mathrm{I}_{\alpha}$ and $\mathrm{I}_{\beta}$ in cellulose. According to Sugiyama et al. [56], bands at 3240 and $750 \mathrm{~cm}^{-1}$ are assigned to the $I_{\alpha}$, whereas those at 3270 and $710 \mathrm{~cm}^{-1}$ to
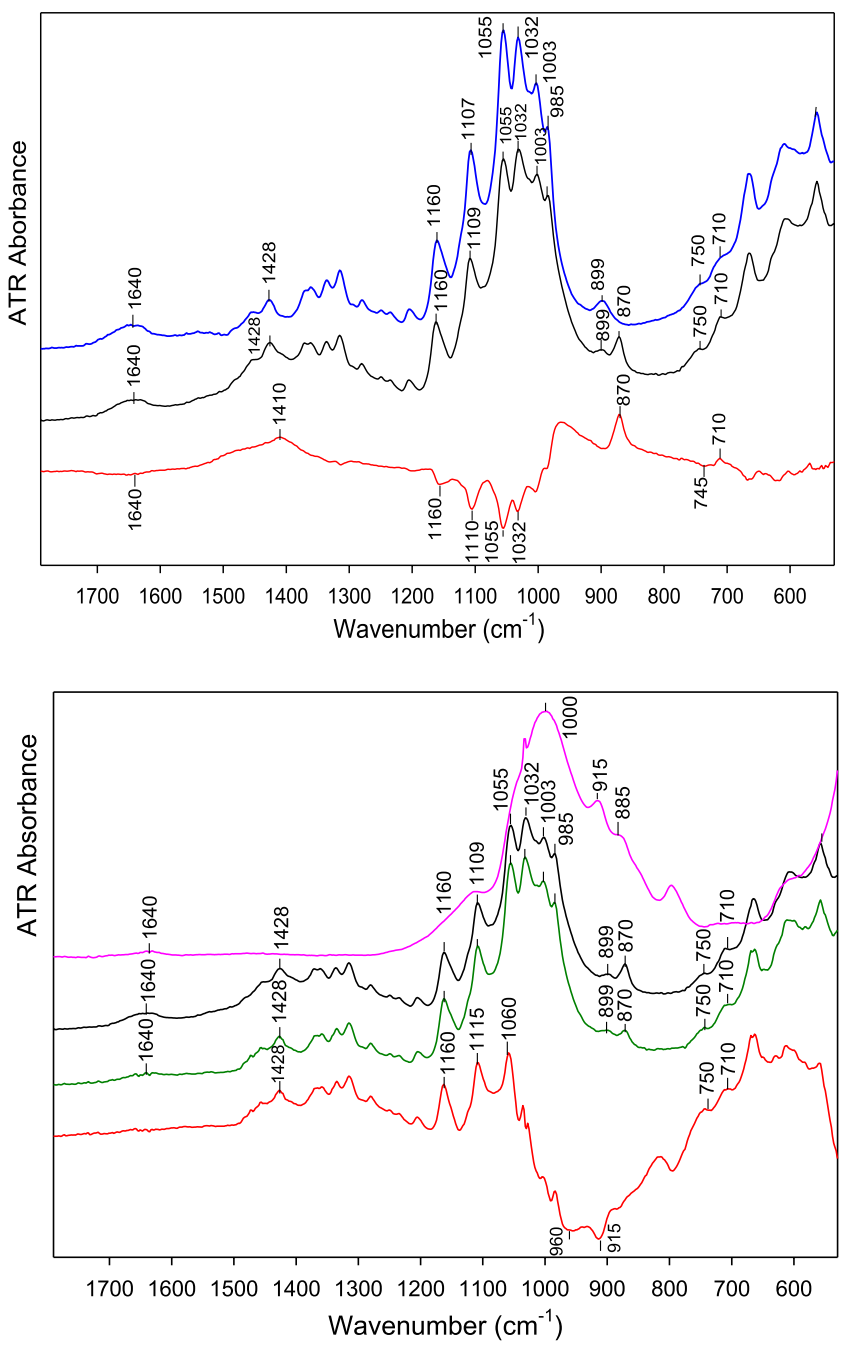

tracted (red line), spectra of glycerol (black line), bBC/MMT (green line) and bBC/MMT/G10 (gray line) are shown for comparison; d differential spectrum of bBC/MMT/G15 after the spectrum of glycerol was subtracted (red line), spectra of glycerol (black line), bBC/ MMT (green line) and bBC/MMT/G15 (purple line), are shown for comparison (Color figure online) 

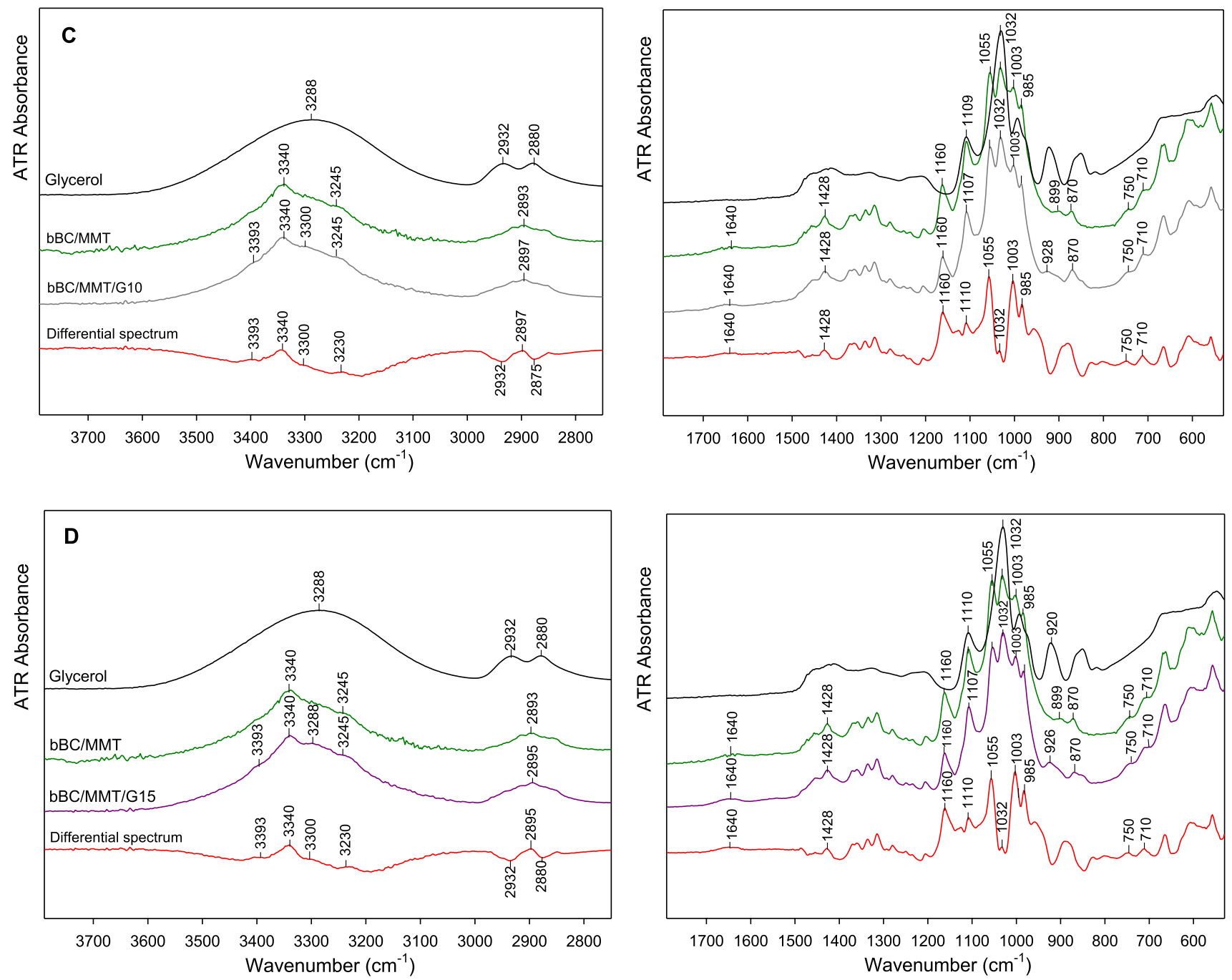

Fig. 4 (continued)

the $\mathrm{I}_{\beta}$, allomorph. It is hard to say unequivocally whether the bands at around $3270-3240 \mathrm{~cm}^{-1}$ are different in the BC and $\mathrm{bBC}$ spectra, but the intensity of the band at $750 \mathrm{~cm}^{-1}$ decreased and this at $710 \mathrm{~cm}^{-1}$ significantly increased due to BC membrane disintegration (Fig. 4a). Based on the formula proposed by Yamamoto et al. [24], it has been shown that the $\mathrm{I}_{\alpha} / \mathrm{I}_{\beta}$ ratio for $\mathrm{BC}$ amounted to 1.41 , and for the bBC 0.89 (Table 4). These results evidently indicate that the proportion of the $I_{\alpha}$ crystalline form decreased, and the $I_{\beta}$ form increased because of the disintegration, and this is also in an agreement with the results obtained from the XRD analysis (Table 4).

Before analyzing the spectra of the bBC modified with MMT, the spectrum of the MTT itself was analyzed. In this spectrum, absorption bands at 3700-3100, 1640, and $1200-800 \mathrm{~cm}^{-1}$ range were observed (Fig. 4b). The maxima of these bands, appearing at 3630, 1640, and $1000 \mathrm{~cm}^{-1}$, respectively, represent $\nu_{\mathrm{OH}}$ in unbounded hydroxyl groups, $\delta_{\mathrm{OH}}$ in hydroxyl groups derived from water molecules, and $\nu_{\mathrm{Si}-\mathrm{O}}$ in the $\mathrm{Si}-\mathrm{O}-\mathrm{Si}$ moiety [57]. In the last band, two maxima were also visible, at 915 and $885 \mathrm{~cm}^{-1}$, which according to Uchino et al. [58], also correspond to $\nu_{\mathrm{Si}-\mathrm{O}}$ in silane moieties.

In the $\mathrm{bBC} / \mathrm{MMT}$ spectrum, apart from characteristic bands for the bBC, no additional bands were observed (Fig. 4b). Negative peaks centred at 960 and $915 \mathrm{~cm}^{-1}$ in the differential spectrum, resulting from the subtraction of the MMT from the bBC/MMT spectrum (Figs. 3, 4b), may indicate that MMT was not embedded in the polymer's structure matrix. However, the band centered at $3282 \mathrm{~cm}^{-1}$ in the $\mathrm{bBC/MMT}$ second-derivative spectrum exhibited a shoulder at $3295 \mathrm{~cm}^{-1}$, while no shoulder was observed in the band at 3290 and $3289 \mathrm{~cm}^{-1}$ in the s second-derivative spectrum of the BC and the bBC, respectively. This shoulder could be an outcome of $\nu_{\mathrm{OH}}$ vibrations, associated with 
Table 5 Infrared spectral characteristic of BC

\begin{tabular}{ll}
\hline Band assignment & Position $\left(\mathrm{cm}^{-1}\right)$ \\
\hline$\nu_{\mathrm{OH}}$ intramolecular H-bonds for $3 \mathrm{O} \cdots \mathrm{H}-\mathrm{O} 5$ and & 3390 \\
$2 \mathrm{O} \cdots \mathrm{H}-\mathrm{O} 6$ & \\
$\nu_{\mathrm{OH}}$ intramolecular H-bonds for $3 \mathrm{O} \cdots \mathrm{H}-\mathrm{O} 5$ & 3346 \\
$\nu_{\mathrm{OH}}$ intermolecular H-bonds & 3300 \\
$\nu_{\mathrm{OH}}$ intermolecular H-bonds for $6 \mathrm{O} \cdots \mathrm{H}-\mathrm{O} 3$ & 3245 \\
$\nu_{\mathrm{CH}}$ & 2897 \\
$\delta_{\mathrm{OH}}$ polimer bound $\mathrm{H}_{2} \mathrm{O}$ & 1640 \\
$\delta_{\mathrm{CH}}, \delta_{\mathrm{OH}}$ & 1428 \\
$\nu_{\mathrm{C}-\mathrm{O}-\mathrm{C}}$ of $1 \mathrm{C}-\mathrm{O}-\mathrm{C} 4$ & 1160 \\
$\delta_{\mathrm{C}-\mathrm{OH}}$ of $2 \mathrm{C}-\mathrm{OH}$ & 1107 \\
$\delta_{\mathrm{C}-\mathrm{OH}}$ of 3C-OH & 1055 \\
$\nu_{\mathrm{C}-\mathrm{O}}$ of $6 \mathrm{C}-\mathrm{OH}$ & 1032 \\
$\nu_{\mathrm{C}-\mathrm{O}}$ & 1003 \\
$\nu_{\mathrm{C}-\mathrm{O}}$ & 985 \\
$\beta-$ glycosidic linkage & 899 \\
anomeric region of carbohydrates, $\delta_{\mathrm{CH}}$ & 870 \\
$\mathrm{I}_{\alpha}, \delta_{\mathrm{OH}}$ out-of-plane & 750 \\
$\mathrm{I}_{\beta}, \delta_{\mathrm{OH}}$ out-of-plane & 710 \\
\hline
\end{tabular}

the intermolecular interaction of the $\mathrm{OH}$ groups in the $\mathrm{bBC}$ structure in the MMT presence.

In the spectrum of glycerol, an absorption band in the $3500-3000 \mathrm{~cm}^{-1}$ range, corresponding to $\nu_{\mathrm{OH}}$, and a band with a double maximum at 2932 and $2880 \mathrm{~cm}^{-1}$, corresponding to $\delta_{\mathrm{CH}}$, were observed (Fig. 4c). Furthermore, a band in the range of $1500-1200 \mathrm{~cm}^{-1}$, assigned to $\delta_{\mathrm{CH}}$ in secondary alcohols, and a band in the $1100-900 \mathrm{~cm}^{-1}$ range, with a maximum at $1032 \mathrm{~cm}^{-1}$, attributed to the $\mathrm{C}-\mathrm{O}$ primary alcohol tensile vibrations [59], were also noted.

The addition of glycerol to the bBC/MMT led to an increase in the intensity of the bands in the $3600-3000 \mathrm{~cm}^{-1}$ range, with four positive peaks clearly visible at 3393,3340 , 3300 and $3230 \mathrm{~cm}^{-1}$ in the differential spectrum (Fig. 4c). Since all these peaks are assigned to inter- and intramolecular hydrogen-bonded $v_{\mathrm{OH}}$, the increase in the number of hydrogen bonds between the $\mathrm{OH}$ groups in the $\mathrm{bBC} /$ MMT films in the presence of glycerol was demonstrated [60]. These observations are confirmed by the analysis of the second-derivative spectra of the bBC/MMT/G10 and the $\mathrm{bBC} / \mathrm{MMT} / \mathrm{G} 15$, in which clearly defined shoulders at 3293 and $3295 \mathrm{~cm}^{-1}$, respectively, were observed (Fig. 5). Moreover, an increase in the intensity of the bands in the $1055-985 \mathrm{~cm}^{-1}$ region in the spectra of the bBC/MMT plasticized with glycerol, with positive peaks clearly visible in the differential spectra (Fig. 4c), were also observed. An increase in the intensity of that band was the greater, the more plasticizer was added (Fig. 4d).

Crystallinity indexes calculated on the basis of FTIR spectra are widely described in the literature by different authors, when indicating changes in the structure of cellulose. Therefore, the most recurring ones, i.e.: TCI, LOI and $\mathrm{HBI}$, were calculated to estimate changes in the $\mathrm{BC}$ structure caused by its modification.
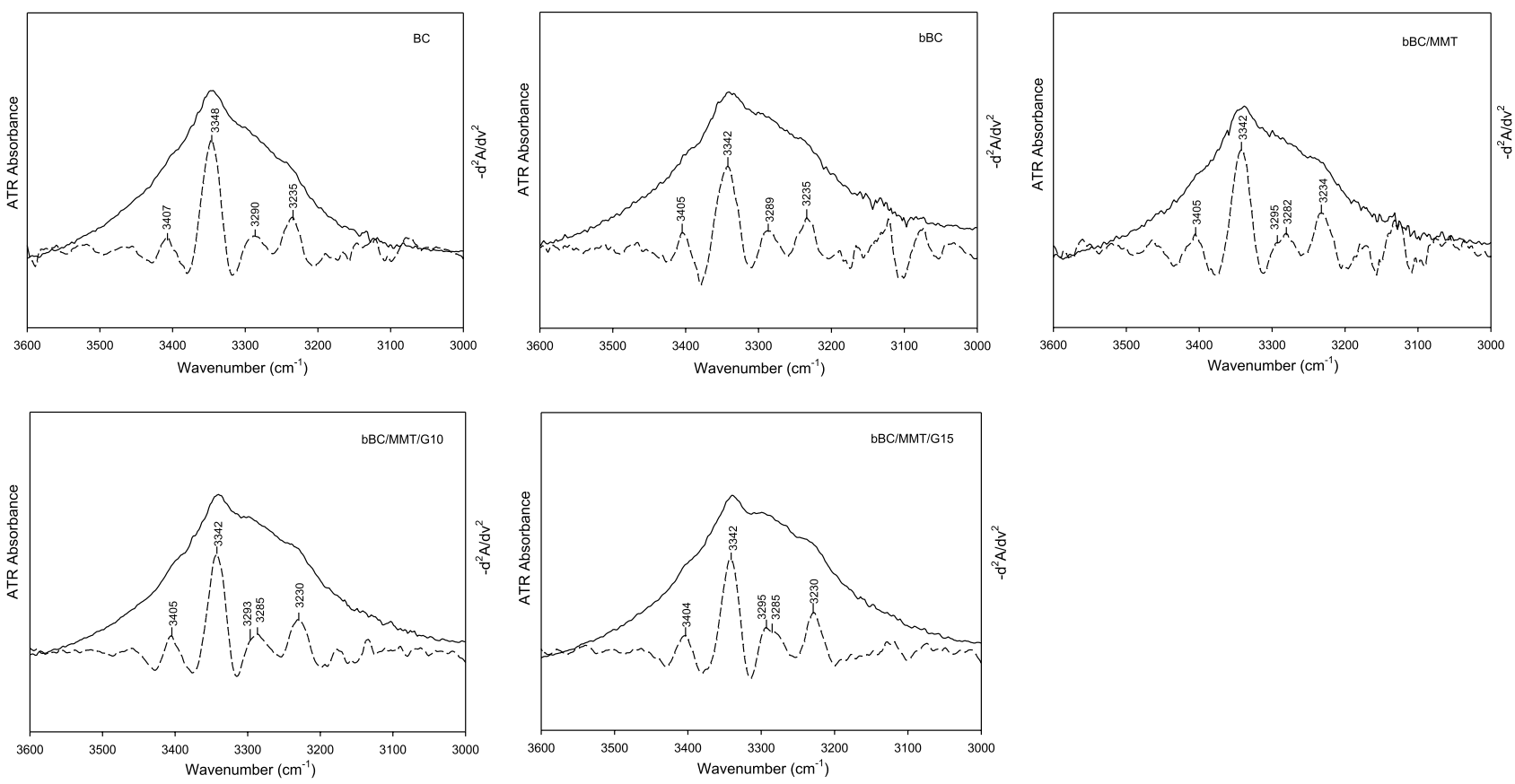

Fig. 5 Absorbance and second-derivative spectra of the BC and bBC-based films 
The data listed in Table 4 evidently confirm that the crystallinity of the $\mathrm{BC}$ rose due to disintegration of its membranes, as the TCI and LOI indexes, calculated from the absorbance ratios $\mathrm{A}_{1372} / \mathrm{A}_{2897}$ and $\mathrm{A}_{1430} / \mathrm{A}_{893}$, respectively, increased. The HBI index, estimated from the absorbance ratio $\mathrm{A}_{3336} / \mathrm{A}_{1336}$, decreased at once, as the the intensity of the band at $1336 \mathrm{~cm}^{-1}$, assigned to the hydrogen bonds characteristic of the crystalline form of cellulose [61], increased. This observed trend follows previous findings described by Kljun et al. [62]. Modification of the $\mathrm{bBC}$ with MMT rearranged the $\mathrm{bBC}$ structure only slightly, the TCI and LOI indexes slightly increased, while HBI index decreased. However, plasticization of bBC/MMT significantly increased both the TCI and LOI indexes, and decreased the HBI index.

\section{Conclusion}

The influence of disintegration of $\mathrm{BC}$ and addition of MMT on its water barrier, mechanical and thermal properties was investigated to see if the so modified BC is suitable for biodegradable food packaging material. The function-structure relationship of resulting films due to different interactions among their components was discussed too. The disintegration of BC membranes resulted in the scission of intramolecular hydrogen and glycoside bonds in the cellulose structure, leading to the release of free $\mathrm{OH}$ groups. This enabled the formation of new intermolecular hydrogen bonds and a partial conversion from the $I_{\alpha}$ to $I_{\beta}$ allomorph, and in the increase in Cr.I. and thermal stability. Unfortunately, the increase in WVP and the decrease in $\sigma$ also took place. Modification of the bBC with MMT rearranged the bBC structure only slightly. The addition of $2 \%$ of montmorillonite did not affect the WVP and the $\sigma$ of the bBC, while $5 \%$ addition increased WVP without changing $\sigma$. In the presence of glycerol, the improvement of water barrier properties of the $\mathrm{bBC}$ modified by adding $2 \%$ of MMT was caused by the forming of hydrogen bonds network between components of composite. Neither addition of MMT nor glycerol did affect the degree of bBC crystallinity, while thermal stability of all the bBC/MMT films obtained, both unplasticized and plasticized, was higher than that of the BC. The results indicate the potential usefulness of $\mathrm{BC}$ modified by disintegration and adding $2 \%$ of MMT and 10-15\% of glycerol as a food packaging material.

Acknowledgements The authors acknowledge with thanks the expert laboratory assistance of Mrs. Natalia Lipiak. This research did not receive any specific grant from funding agencies in the public, commercial, or not-for-profit sectors.

\section{Compliance with Ethical Standards}

Conflict of interest The authors declare that they have no conflict of interest.

Open Access This article is licensed under a Creative Commons Attribution 4.0 International License, which permits use, sharing, adaptation, distribution and reproduction in any medium or format, as long as you give appropriate credit to the original author(s) and the source, provide a link to the Creative Commons licence, and indicate if changes were made. The images or other third party material in this article are included in the article's Creative Commons licence, unless indicated otherwise in a credit line to the material. If material is not included in the article's Creative Commons licence and your intended use is not permitted by statutory regulation or exceeds the permitted use, you will need to obtain permission directly from the copyright holder. To view a copy of this licence, visit http://creativecommons.org/licenses/by/4.0/.

\section{References}

1. Abdul-Khalil HPS, Chong EWN, Owolabi FAT, Asniza M, Tye YY, Nurul-Fazita MR, Mohamad-Haafiz MK, Nurmiati Z, Paridah MT (2019) Enhancement of basic properties of polysaccharide-based composites with organic and inorganic fillers: a review. J Appl Polym Sci. https://doi.org/10.1002/APP.47251

2. Shah N, Ul-Islam M, Khattak WA, Park JK (2013) Overview of bacterial cellulose composites: a multipurpose advanced material. Carbohydr Polym 98:1585-1598. https://doi.org/10.1016/j.carbp ol.2013.08.018

3. Yamanaka S, Watanabe K, Kitamura N (1989) The structure and mechanical properties of sheets prepared from bacterial cellulose. J Mater Sci 24:3141-3145

4. Iguchi M, Yamanaka S, Budhiono A (2000) Review. Bacterial cellulose-a masterpiece of nature's arts. J Mater Sci 35:261-270

5. Gea S, Torres FG, Troncoso OP, Reynolds CT, Vilasecca F, Iguchi M, Peijs T (2007) Biocomposites based on bacterial cellulose and apple and radish pulp. Int Polym Process 22:497-501. https://doi. org/10.1016/j.lwt.2007.11.023

6. Qiu K, Netravali AN (2014) A review of fabrication and applications of bacterial cellulose based nanocomposies. Polym Rev 54:598-626. https://doi.org/10.1080/15583724.2014.896018

7. Ul-Islam M, Khan T, Park JK (2012a) Water holding and release properties of bacterial cellulose obtained by in situ and ex situ modification. Carbohydr Polym 88:596-603. https://doi. org/10.1016/j.carbpol.2012.01.006

8. Ul-Islam M, Khan T, Park JK (2012b) Nanoreinforced bacterial cellulose-montmorillonite composites for biomedical applications. Carbohydr Polym 89:1189-1197. https://doi.org/10.1016/j.carbp ol.2012.03.093

9. Wang Q, Guo J, Xu D, Cai J, Qiu Y, Ren J, Zhang L (2015) Facile construction of cellulose/montmorillonite nanocomposite biobased plastics with flame retardant and gas barrier properties. Cellulose 22:3799-3810. https://doi.org/10.1007/s 1057 0-015-0758-0

10. Zeng QH, Yu AB, Lu GQ, Paul DR (2005) Clay-based polymer nanocomposites: research and commercial development. J Nanosci Nanotechnol 5:1574-1592. https://doi.org/10.1166/ jnn.2005.411

11. Oh SY, Yoo DI, Shin Y, Kim HC, Kim HY, Chung YS, Park WH, Youk JH (2005) Crystalline structure analysis of cellulose treated with sodium hydroxide and carbon dioxide by means of X-ray 
diffraction and FTIR spectroscopy. Carbohydr Res 340:23762391. https://doi.org/10.1016/j.carres.2005.08.007

12. Kondo T, Rytczak P, Bielecki S (2016) Bacterial nanocellulose characterization. In: Gama F, Dourado F, Bielecki S (eds) Bacterial nanocellulose. From biotechnology to bio-economy. Elsevier, Amsterdam

13. Crocker M (2010) Thermochemical conversion of biomass to liquid fuels and chemicals. RSC Publishing, Cambridge

14. Wang S, Luo Z (2017) Pyrolysis of biomass. De Gruyter together with China Science Publishing \& Media Ltd., Beijing

15. Moon RJ, Martini A, Nairn J, Simonsen J, Youngblood J (2011) Cellulose nanomaterials review: structure, properties and nanocomposites. Chem Soc Rev 40:3941-3994. https://doi. org/10.1039/C0CS00108B

16. Bielecki S, Kołodziejczyk M, Kowalska K, Krystynowicz A, Pankiewicz T (2010) Sposób wytwarzania biomateriału o właściwościach chrząstki, przeznaczonego na implanty dla chirurgii rekonstrukcyjno-odtwórcze. PL390650A

17. Hestrin S, Schramm M (1954) Synthesis of cellulose by Acetobacter xylinum. 2. Preparation of freeze-dried cells capable of polymerizing glucose to cellulose. Biochem J 58:345-352. https ://doi.org/10.1042/bj0580345

18. ASTM (1995) Standard test methods for water vapour transmission of material. E96-95. American Society for Testing and Materials, Philadelphia

19. ASTM (2001) Standard test method for tensile properties of thin plastic sheeting. Annual book of ASTM. American Society for Testing and Materials, Philadelphia

20. Segal L, Creely JJ, Martin A, Conrad CM (1959) An empirical method for estimating the degree of crystallinity of native cellulose using the X-ray diffractometer. Text Res J 29:786-794. https ://doi.org/10.1177/004051755902901003

21. Nelson ML, O'Connor RT (1964) Relation of certain infrared bands to cellulose crystallinity and crystal lattice type. Part II. A new infrared ratio for estimation of crystallinity in celluloses I and II. J Appl Polym Sci 8:1325-1341. https://doi.org/10.1002/ app.1964.070080323

22. Hurtubise FG, Krässig H (1960) Classification of fine structural characteristics in cellulose by infrared spectroscopy use of potassium bromide pellet technique. Anal Chem 32:177-181. https:// doi.org/10.1021/ac60158a010

23. Nada AAMA, Kamel S, El-Sakhawy M (2000) Thermal behaviour and infrared spectroscopy of cellulose carbamates. Polym Degrad Stab 70:347-355. https://doi.org/10.1016/S0141-3910(00)00119 $-1$

24. Yamamoto H, Horii F, Hirai A (1996) In situ crystallization of bacterial cellulose II. Influences of different polymeric additives on the formation of celluloses I $\alpha$ and I $\beta$ at the early stage of incubation. Cellulose 3:229-242. https://doi.org/10.1007/bf02228804

25. Padrão J, Gonçalves S, Silva JP, Sencadas V, Lanceros-Méndez S, Pinheiro AC, Vicente AA, Rodrigues LR, Dourado F (2016) Bacterial cellulose-lactoferrin as an antimicrobial edible packaging. Food Hydrocoll 58:126-140. https://doi.org/10.1016/j.foodh yd.2016.02.019

26. Clasen C, Sultanova B, Wilhelms T, Heisig P, Kulicke W-M (2006) Effects of different drying processes on the material properties of bacterial cellulose membranes. Macromol Symp 244:4858. https://doi.org/10.1002/masy.200651204

27. Tomé LC, Brandão L, Mendes AM, Silvestre AJD, Neto CP, Gandini A, Freire CSR, Marrucho IM (2010) Preparation and characterization of bacterial cellulose membranes with tailored surface and barrier properties. Cellulose 17:1203-1211. https:// doi.org/10.1007/s10570-010-9457-z

28. Stoica-Guzun A, Stroescu M, Jinga SI, Jipa IM, Dobre T (2013) Microwave assisted synthesis of bacterial cellulose-calcium carbonate composites. Ind Crops Prod 50:414-422. https://doi. org/10.1016/j.indcrop.2013.07.063

29. Vieira MGA, da Silva MA, dos Santos LO, Beppu MM (2011) Natural-based plasticizers and biopolymer films: a review. Eur Polym J 47:254-263. https://doi.org/10.1016/j.eurpo lymj.2010.12.011

30. Cazón P, Velazquez G, Vázquez M (2020) Characterization of mechanical and barrier properties of bacterial cellulose, glycerol and polyvinyl alcohol (PVOH) composite films with eco-friendly UV-protective properties. Food Hydrocoll 99:105323. https://doi. org/10.1016/j.foodhyd.2019.105323

31. Ghanbarzadeh B, Musavi M, Oromiehie AR, Rezayi K, Razmi Rad E, Milani J (2007) Effect of plasticizing sugars on water vapor permeability, surface energy and microstructure properties of zein films. LWT Food Sci Technol 40:1191-1197. https://doi. org/10.1016/j.lwt.2006.07.008

32. Staroszczyk H, Gottfried K, Malinowska-Pańczyk E, Kołodziejska I (2017) Clay-filled starch films. Part I: Effect of clay kind and glycerol concentration on functional properties of composites. Starch/Staerke 69:1-8. https://doi.org/10.1002/star.201500325

33. Martucci JF, Vázquez A, Ruseckaite RA (2007) Nanocomposites based on gelatin and montmorillonite: morphological and thermal studies. J Therm Anal Calorim 89:117-122. https://doi. org/10.1007/s10973-006-7454-0

34. Yousefi H, Faezipour M, Hedjazi S, Mousavi MM, Azusa Y, Heidari AH (2013) Comparative study of paper and nanopaper properties prepared from bacterial cellulose nanofibers and fibers/ground cellulose nanofibers of canola straw. Ind Crops Prod 43:732-737. https://doi.org/10.1016/j.indcrop.2012.08.030

35. Soykeabkaew N, Sian C, Gea S, Nishino T, Peijs T (2009) Allcellulose nanocomposites by surface selective dissolution of bacterial cellulose. Cellulose 16:435-444. https://doi.org/10.1007/ s10570-009-9285-1

36. Ziani K, Oses J, Coma V, Maté JI (2008) Effect of the presence of glycerol and Tween 20 on the chemical and physical properties of films based on chitosan with different degree of deacetylation. LWT Food Sci Technol 41:2159-2165. https://doi.org/10.1016/j. lwt.2007.11.023

37. Giannakas A, Grigoriadi K, Leontiou A, Barkoula NM, Ladavos A (2014) Preparation, characterization, mechanical and barrier properties investigation of chitosan-clay nanocomposites. Carbohydr Polym 108:103-111. https://doi.org/10.1016/j.carbp ol.2014.03.019

38. Maeda H, Nakajima M, Hagiwara T, Sawaguchi T, Yano S (2006) Bacterial cellulose/silica hybrid fabricated by mimicking biocomposites. J Mater Sci 41:5646-5656. https://doi.org/10.1007/s1085 3-006-0297-z

39. Yano S, Maeda H, Nakajima M, Hagiwara T, Sawaguchi T (2008) Preparation and mechanical properties of bacterial cellulose nanocomposites loaded with silica nanoparticles. Cellulose 15:111120. https://doi.org/10.1007/s10570-007-9152-x

40. Ul-Islam M, Khattak WA, Kang M, Kim SM, Khan T, Pakr JK (2013) Effect of post-synthetic processing conditions on structural variations and applications of bacterial cellulose. Cellulose 20:253-263. https://doi.org/10.1007/s10570-012-9799-9

41. Xie W, Gao Z, Liu K, Pan W-P, Vaia R, Hunter D, Singh A (2001) Thermal characterization of organically modifed montmorillonite. Thermochim Acta 367-368:339-350

42. Sinha Ray S, Okamoto M (2003) Polymer/layered silicate nanocomposites: a review from preparation to processing. Prog Polym Sci 28:1539-1641. https://doi.org/10.1016/j.progpolyms ci.2003.08.002

43. Cyras VP, Zenklusen MCT, Vazquez A (2006) Relationship between structure and properties of modified potato starch 
biodegradable films. J Appl Polym Sci 101:4313-4319. https:// doi.org/10.1002/app.23924

44. Park H, Lee W, Park C, Cho W, Ha C (2003) Environmentally friendly polymer hybrids. J Mater Sci 38:909-915. https://doi. org/10.1023/A:1022308705231

45. García NL, Ribba L, Dufresne A, Aranguren M, Goyanes S (2011) Effect of glycerol on the morphology of nanocomposites made from thermoplastic starch and starch nanocrystals. Carbohydr Polym 84:203-210. https://doi.org/10.1016/j.carbpol.2010.11.024

46. Goh WN, Rosma A, Kaur B, Fazilah A, Karim A, Bhat R (2012) Microstructure and physical properties of microbial cellulose produced during fermentation of black tea broth (Kombucha). II. Int Food Res J 19:153-158

47. Surma-Ślusarska B, Presler S, Danielewicz D (2008) Characteristics of bacterial cellulose obtained from Acetobacter xylinum culture for application in papermaking. FIBRES Text East Eur 16:108-111

48. Günister E, Pestreli D, Ünlü CH, Atıcı O, Güngör N (2007) Synthesis and characterization of chitosan-MMT biocomposite systems. Carbohydr Polym 67:358-365. https://doi.org/10.1016/j. carbpol.2006.06.004

49. de Moraes CT, Haas Costa TM, de Oliveira RA, Hickmann Flôres $S$ (2016) Valorization of food-grade industrial waste in the obtaining active biodegradable films for packaging. Ind Crops Prod 87:218-228. https://doi.org/10.1016/j.indcrop.2016.04.039

50. van Soest JJG, Hubertus T, de Wit D, Vliegenthart JFG (1995) Short-range structure in (partially) crystalline potato starch determined with attenuated total reflectance Fourier-transform IR spectroscopy. Carbohydr Res 279:201-214. https://doi. org/10.1016/0008-6215(95)00270-7

51. Oh SY, Yoo I, Shin Y, Seo G (2005) FTIR analysis of cellulose treated with sodium hydroxide and carbon dioxide. Carbohydr Res 340:417-428. https://doi.org/10.1016/j.carres.2004.11.027

52. Hishikawa Y, Togawa E, Kondo T (2017) Characterization of individual hydrogen bonds in crystalline regenerated cellulose using resolved polarized FTIR spectra. ACS Omega 2:1469-1476. https ://doi.org/10.1021/acsomega.6b00364

53. Mathlouthi M, Koenig JL (1986) Vibrational spectra of carbohydrates. Adv Carbohyd Chem Biochem 44:7-89. https://doi. org/10.1016/S0065-2318(08)60077-3

54. Velmurugan R, Mohan TP (2009) Epoxy-clay nanocomposites and hybrids: synthesis and characterization. J Reinf Plast Compos 28:17-37. https://doi.org/10.1177/0731684407081439
55. Parker FS (1983) Applications of Infrared, Raman, and resonance Raman spectroscopy in biochemistry, 1983rd edn. Plenum Press, New York

56. Sugiyama J, Persson J, Chanzy H (1991) Combined infrared and electron diffraction study of the polymorphism of native celluloses. Macromolecules 24:2461-2466. https://doi.org/10.1021/ ma00009a050

57. Greesh N, Hartmann PC, Cloete V, Sanderson RD (2008) Adsorption of 2-acrylamido-2-methyl-1-propanesulfonic acid (AMPS) and related compounds onto montmorillonite clay. J Colloid Interface Sci 319:2-11. https://doi.org/10.1016/j.jcis.2007.10.019

58. Uchino T, Sakka T, Hotta K, Iwasaki M (1989) Attenuated total reflectance Fourier-transform infrared spectra of a hydrated sodium soilicate glass. J Am Ceram Soc 72:2173-2175. https:// doi.org/10.1111/j.1151-2916.1989.tb06051.x

59. Treinyte J, Grazuleviciene V, Ostrauskaite J (2014) Biodegradable polymer composites with nitrogen- and phosphorus-containing waste materials as the fillers. Ecol Chem Eng Sci 21:515-528. https://doi.org/10.2478/eces-2014-0038

60. da Silva MA, Bierhalz ACK, Kieckbusch TG (2009) Alginate and pectin composite films crosslinked with $\mathrm{Ca}^{2+}$ ions: effect of the plasticizer concentration. Carbohydr Polym 77:736-742. https:// doi.org/10.1016/j.carbpol.2009.02.014

61. Kondo T, Sawatari C (1996) A Fourier transform infra-red spectroscopic analysis of the character of hydrogen bonds in amorphous cellulose. Polymer 37:393-399. https://doi.org/10.1016/00323861(96)82908-9

62. Kljun A, Blackburn RS, Benians TAS, Knox JP, Goubet F, Meulewaeter F (2011) Comparative analysis of crystallinity changes in cellulose i polymers using ATR-FTIR, X-ray diffraction, and carbohydrate-binding module probes. Biomacromol 12:4121-4126. https://doi.org/10.1021/bm201176m

Publisher's Note Springer Nature remains neutral with regard to jurisdictional claims in published maps and institutional affiliations. 